\title{
INFLUENCE OF NATIONAL CULTURE ON BEHAVIOR OF BUSINESS: COMPARATIVE STUDY OF SLOVAKIA AND UKRAINE
}

\author{
Nataliia Ostapenko \\ Taurida National V.I.Vernadsky University \\ natayal107@mail.ru
}

\begin{abstract}
This article examines the influence of national culture on the behavior of enterprises by comparing two countries - Ukraine and Slovakia. The data is based on the original author's own research on the enterprises of Ukraine and Slovakia. The paper is investigated why and how cultural factors (informal institutions) may influence the perception of companies of rules of the game, and the formation of appropriate behavior. On the basis of surveys conducted among enterprises of Ukraine and Slovakia main conclusions about current formal rules of the game in these countries, perception by entrepreneurs these rules and the formation of certain behavior by them are done. In work on the basis of comparative analysis conclusions about the impact of national culture on the development of entrepreneurship in the national economy are done. The author of the article examines the following indicators: national culture, personal characteristics of respondents, subordination of norms, opportunism, and coherence of formal and informal institutions at the national level. In particular the most important indicators of the perception of norms are: indicators of perception of entrepreneurs of regulation and public policies in the field of entrepreneurship, business productivity, perceptions of bribery and tax evasion, etc.
\end{abstract}

\section{Keywords}

national culture; business; Slovakia; Ukraine; behavior

\section{JEL Classification}

Z10; D03

\section{Introduction}

The main problems of economic policy in the sphere of macroeconomic regulation of development of small business lies in the fact that the development of programs for development and stimulation of small business doesn't consider features of institutional environment of concrete national economy, and is based only on an estimated assessment of efficiency of the concrete "torn-off" actions. At this point, the mechanism of regulation is developed without taking into account existing institutional framework of the national economy, particularly from existing informal institutions rooted in economy. Some foreigner authors point out importance of taking into account the existing informal institutions in national economy: North, 1990; Von Hirschhausen C., 1990; Libman A., 2007; Domjahn T., 2011. In this case, the traditional and the new institutional theory determines that informal institutions (informal norms of behavior which are forming of habits, customs, mentality and cultural patterns of behavior that shape the behavior of people in society) have a significant impact on economic development. Informal institutions are unique to a particular model of the national economy, and the impact of these institutions may negate the effect of any law, which could lead to an institutional trap and reduce the efficiency of development of the national economy. Informal institutions shape the 
interpretation of the entrepreneurs of formal rules of the game, i.e. determine their effectiveness.The sociocultural environment influence entrepreneurial attitudes and motives, the resources that can be mobilized as well as the constraints and opportunities on/for starting and running a business (Martinelli, 2004). Therefore, to understand the effects of home country institutional constraints on the behavior and performance of business sector, it seems more appropriate to focus on study of affects of culture on this prosses.

Organizational behavior with respect to institutional pressures is locally specific and differs with respect to experiences and backgrounds of entrepreneurs, nationality, industry and culture (DiMaggio, 1988). Williamson pointed out, that under incomplete contracting (Williamson, 1988) the extent to which agency costs and asymmetric information problems can be mitigated by an appropriate choice of financial contracts depends largely on a country's contracting environment, which includes both formal institutions, such as legal and economic rules, and informal institutions, such as norms, customs and religions (North, 1990; Williamson, 2000). North (1990) observes that the informal constraints that stem from culture have a more pervasive influence than formal laws and property rights in shaping choices in daily interactions. Fukuyama (1995) recognizes the trend of similarity in many countries of major institutions of government and economic regulation, accompanied by differences in economic performance, which leads to the assumption that deepseated cultural differences between societies explain the observed difference in performance. Aidis R. (2006) identifies the main barriers to the small business sector in various stages of transition, and among the influencing factors on the initial conditions of a country defined geographical factors, cultural and institutional legacy of central planning. According to this in our analysis countries are selected (Ukraine and Slovakia), which are similar in terms of historical, cultural, institutional development, as well as legal origin (La Porta,1999) But at the same time, in these countries at the moment small business sector developing differently. Paul G (2001) notes that the institutional environment influences the behavior of enterprises in different ways, and the effects of changes in the behavior of enterprises lead to different economic outcomes.

The aim of this research is to investigate the influence of cultural factors (traditions, mentality) on development of small business and productivity of its macroeconomic regulation.

\section{Literature review. Culture}

Culture is a comprehensive system of meanings, symbols, values, and assumptions about what is good or bad, legitimate or illegitimate which underlies the practices and norms in a society (Hofstede, 1999). In a very similar way, Geertz (1957) noted that culture is a web of meanings, in terms of which human beings interpret their existence and experience, and drive their actions, that is, cultures are models of human behavior and symbolic structures that give meaning to their conducts. Culture influences and pervades every aspect of life and, although it is not deterministic, it is subliminal system of thought that reflects the organization of values, norms and symbols of a particular society and influences the interactions and choices of individuals (Parsons and Shils, 1990). As noted by North (1990) «culture provides a language-based conceptual framework for encoding and interpreting the information that the senses are presenting to the brain» thereby shaping human actors' perceptions of the external world and influencing their decisions and behaviors. Culture also influences how individuals process information and shapes their subjective mental constructs used to 
interpret problems faced in life, which in turn affects their decision-making (North, 1990). In his study of Asian societies, Weggel (1989) defined culture as the totality of learned behaviors, attitudes, value systems and know-how which is shared and transmitted between members of a larger group. Culture is transmitted slowly over time, from one generation to the next, but it also reflects the current environment.

In sum, the above discussion suggests that culture influences economic activities through two mechanisms. First, based on the model of Williamson (2000), culture conditions formal institutions and hence indirectly affects economic outcomes as suggested by Licht et al. (2005). Second, culture exerts a direct impact on economic activities through its role as an informal constraint on opportunistic behaviors and through its influence on human actors' actions and decision-making by shaping their incentives and subjective perceptions of the external world (Akerlof and Kranton 2000; Rabin 1993). Direct impact of culture on expectations and preferences was reflected in the works Henrich et al., 2001; Bornhorst, Ichino, Schlag and Winter, 2005.

\section{Culture and entrepreneurship}

Culture first of all influences the ways information is processed, thus shaping the patterns of informal institutions (Boyd and Richerson, 1994). Moreover, culture affects patterns of entrepreneurial behavior. Cultural norms determine whether a society tolerates profit-making behavior as a prerequisite for entrepreneurial actions. While most studies implicitly understand entrepreneurship and enterprise behavior as a result of person-specific resources and capabilities, empirical evidence indicates that the dominant feature influencing the nature and pace of entrepreneurship is the external environment (Peng and Heath, 1996; Peng, 2000). They define what actors can do, what is expected from them, or they must do, and what is advantageous for them. In this way, they give stability and predictability to economic interaction (Dallago, 2000). In institutional terms, enterprise behavior is understood as a reaction to inadequate formal and informal institutions leaving little scope to explain emergent behavior (Welter, 2002). Another concept draws attention to external political, economic and societal influences on individual behavior, discussing them in terms of formal and informal institutions (Hoskisson et al., 2000; Peng 2000). One more approach to study development of small business from a position of the institutional theory is based on researches of coherence of formal and informal institutions (Welter and Smallbone (2005), Hernan Roxas et al. (2008)). The sociocultural context not only affects the perception of a situation or a rule, but it also affects the evaluation of the alternative behaviors and their consequences (Hunt and Vitell, 1986).

A large number of empirical studies have suggested the influence of national culture on firm performance. National culture has, for example, been shown to have a greater impact on employees than has the organizational culture of the firm (Adler, 1986). National culture can influence managerial decision-making, leadership style and human resource management practices (Puffer, 1993). All these factors influence a firm's performance in acquiring and deploying resources.

Giannetti and Simonov's (2004) study found evidence that social norms did have some impact on entrepreneurial entry in Sweden. The findings from these studies are mixed, but may be analogous to similar research that suggests cultural values and beliefs do have an ability to impact (over and above structural factors) the explanatory power of group guidelines on new firm formation (e.g., Davidsson, 1995)

Some of the existing literature on cultural differences in entrepreneurship suggests that entrepreneurs from different countries are more alike than non-entrepreneurs from the same country (McGrath and MacMillan, 1992). Yet, other studies suggest 
the attributes of entrepreneurs differ drastically across cultures and countries (Thomas and Mueller, 2000). Hofstede (1980) pointed out that greater opportunities for entrepreneurship typically exist in long-term oriented cultures such as Korea, Taiwan, China and Japan. Busenitz and Lau (1996) also posited cultures that put less value on power distance would favor entrepreneurship. Analyzing entrepreneurial behavior from trust-based cultural and sectoral perspectives, Welter (2004) conclude that the specific structures of formal and informal institutions, the path dependence of informal rules within cultures and sectors, and incompatible formal and informal institutions assist in explaining certain forms of enterprise behavior in Western and Eastern Europe. Culture can also affect behavior and outcomes through its effect on political preferences of individuals about what governments should do: for example, how much government should intrude in economic life, promote competition, regulate the market, redistribute income, run a social security program, or nationalize certain industries and businesses.

A number of conceptualizations have been offered in the literature to identify and measure dimensions of national cultures (e.g., Hofstede, 1980; Schwartz, 1994; Schwartz \& Bilsky, 1987, 1990). The most popular among them are Hofstede and World Value Surveys (Tabellini, 2005; Inglehart, 2000).

\section{Methodology}

In the work we will test such factors as historical heritage, geographical location and cultural heritage (as pointed out Aidis R., 2006). From this point of view, I choose Ukraine and Slovakia for comparative study. These countries are nearby geographical location, they are close by historical development. They long time were under rule of other countries, they are also similar by the communist past, although it should be noted that in Ukraine Communist regime acted much longer. These countries are similar as well as for cultural development, one nation - the Slavs, but it should be noted that Slovakia is Catholic country, and Ukraine is Orthodox.

This work will be carried out on the primary data- i.e. own survey data enterprises of Ukraine and Slovakia. Studied indicators are selected on the basis of Welter F. individual characteristics, mental and functional at the individual level and the historical, regulatory and structural at level of society. The idea of religion being a determinant of culture draws on Max Weber's thesis of a positive relationship between Protestantism and capitalism use cultural factors - thrift, hard work, tenacity, honesty, and tolerance-contrast with the xenophobia, religious intolerance, bureaucratic corruption, and state edicts that stifle enterprise. Tabellini (2005) measures culture as the "principal component" of four values: trust, beliefs in the importance of individual effort, generalized morality, and obedience (which he considers a negative value), conviction that individual effort is likely to pay off, respect for other people which are inferred from questions on the World Values Survey.

\section{Empirical research}

In table 1 we investigate the quality of the existing rules in the field of entrepreneurship, as well as perception by entrepreneurs of quality of these rules. These figures are quite important, as they define how the enterprise "willing to play" according to the rules (even if they are not effective). Table 1 presents percent of 
respondents of enterprises of Slovakia and Ukraine in terms of agreement with some statements (table 1).

Table 1 Results of survey of enterprises of Ukraine and Slovak of perception of formal rules of the game

\begin{tabular}{|c|c|c|c|c|c|c|c|c|}
\hline & \multicolumn{2}{|c|}{ 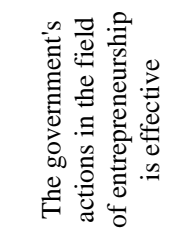 } & \multicolumn{2}{|c|}{ 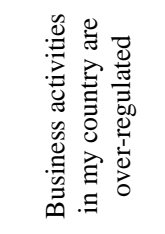 } & \multicolumn{2}{|c|}{ 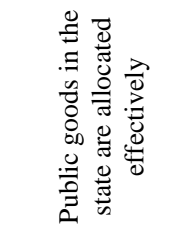 } & \multicolumn{2}{|c|}{ 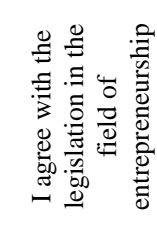 } \\
\hline & Ukr & Sk & Ukr & Sk & Ukr & Sk & $\mathrm{Ukr}$ & Sk \\
\hline Completely agree & 2,4 & 0 & 31,7 & 26,6 & 2,4 & 0 & 2,4 & 2,5 \\
\hline Rather agree & 4,8 & 7,6 & 24,4 & 21,5 & 7,3 & 2,6 & 9,7 & 7,6 \\
\hline 50 on 50 & 16,7 & 10,3 & 31 & 25,3 & 12,2 & 10,4 & 31,7 & 10,1 \\
\hline Rather disagree & 30,9 & 17,9 & 4,8 & 13,9 & 19,5 & 18,2 & 12,2 & 29,1 \\
\hline Do not Agree & 45,2 & 64,1 & 7,1 & 12,7 & 58,6 & 68,9 & 43,9 & 50,7 \\
\hline Correlation & \multicolumn{2}{|l|}{0,9} & \multicolumn{2}{|l|}{0,99} & \multicolumn{2}{|c|}{0,998} & \multicolumn{2}{|l|}{0,72} \\
\hline
\end{tabular}

As we can see from table 1, between Slovaks enterprises there are more opinion that government actions in sphere of entrepreneurship is ineffective (64\% not agree), that may consider that Slovak enterprises are more involved in the formation of the rules of the game and believe that they can change it. Second indicator «Business activities in my country are over-regulated» is similar in both countries (correlation 0, 99). So business don't think that regulation is efficient and optimal, they don't agree with this. Business in both countries also doesn't think that public goods in the state are allocated effectively. In indicator «I agree with the legislation in the field of entrepreneurship» Slovak enterprises is more negative, which can assume, that Slovaks may more express their feeling and disagree on certain questions.

In table 2 we investigate results of survey of enterprises by parameters of personal characteristics and performance of their business. These indicators reflect the impact of culture on the behavior of entrepreneurs. As we can see (table 2), this indicators is quite different by countries.

Table 2 Results of survey of enterprises of Ukraine and Slovak of personal characteristics and performance of their business

\begin{tabular}{|c|c|c|c|c|c|c|c|c|}
\hline & \multicolumn{2}{|c|}{ 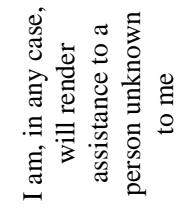 } & \multicolumn{2}{|c|}{ 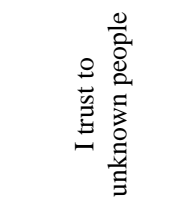 } & \multicolumn{2}{|c|}{ 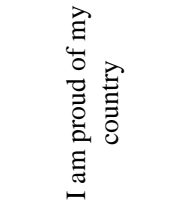 } & \multicolumn{2}{|c|}{ 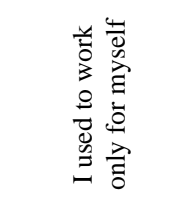 } \\
\hline & Ukr & Sk & Ukr & Sk & Ukr & Sk & Ukr & Sk \\
\hline Completely agree & 45,2 & 60,8 & 19,1 & 10,2 & 40,4 & 55,7 & 36,6 & 43,6 \\
\hline
\end{tabular}




\begin{tabular}{|l|l|l|l|l|l|l|l|l|} 
& & & & & & & \\
Rather agree & 19 & 19 & 26,1 & 16,4 & 14,3 & 20,2 & 21,9 & 16,7 \\
\hline 50 on 50 & 19 & 13,9 & 28,6 & 24,1 & 16,7 & 16,5 & 17,1 & 15,4 \\
\hline Rather disagree & 14,3 & 5,1 & 9,5 & 31,7 & 9,5 & 3,8 & 12,2 & 6,4 \\
\hline & 2,4 & 0 & 16,6 & 17,7 & 19 & 3,8 & 12,2 & 17,9 \\
Do not Agree & 0,98 & \multicolumn{7}{|c|}{0,37} \\
\hline Correlation & \multicolumn{7}{|c|}{ Source: own authors results of survey }
\end{tabular}

Slovak nation is more likely to assist to unknown persons. But in indicator «I trust to unknown people» Slovak nation is more cautious. And we can assume that Slovak enterprises is more rely on their own forces, because by indicator «I used to work only for myself» more responders from Slovak republic are completely agree, but correlation coefficient compared to Ukraine is 0,92. But Slovak nation is more proud of their country. In table 3 we present comparative study of enterprises by perception of opportunistic behavior (table 3).

Table 3 Results of survey of enterprises of Ukraine and Slovak of perception of unscrupulous behavior

\begin{tabular}{|c|c|c|c|c|c|c|c|c|}
\hline & \multicolumn{2}{|c|}{ 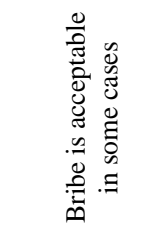 } & \multicolumn{2}{|c|}{ 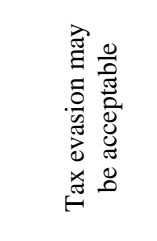 } & \multicolumn{2}{|c|}{ 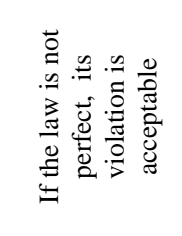 } & \multicolumn{2}{|c|}{ 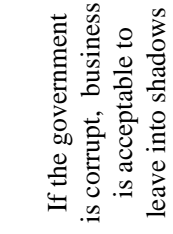 } \\
\hline & $\mathrm{Ukr}$ & Sk & $\mathrm{Ukr}$ & Sk & Ukr & Sk & Ukr & Sk \\
\hline Completely agree & 28,5 & 7,6 & 23,8 & 5,1 & 23,7 & 26,6 & 52,5 & 18 \\
\hline Rather agree & 14,3 & 7,6 & 19 & 1,3 & 19 & 17,7 & 12,5 & 12,5 \\
\hline 50 on 50 & 23,8 & 8,9 & 16,7 & 8,9 & 28,6 & 16,5 & 15 & 30,6 \\
\hline Rather disagree & 9,5 & 19 & 9,5 & 20,3 & 4,8 & 16,5 & 7,5 & 16,7 \\
\hline Do not Agree & 23,8 & 57 & 30,9 & 64,6 & 23,8 & 22,8 & 12,5 & 22,1 \\
\hline Correlation & \multicolumn{2}{|l|}{0,11} & \multicolumn{2}{|l|}{0,58} & \multicolumn{2}{|l|}{0,37} & \multicolumn{2}{|l|}{$-0,07$} \\
\hline
\end{tabular}

As we can see from comparative study (table 3), Slovak business have more negative attitude to the unscrupulous behavior (opportunistic) - correlation between indicators is small or negative. Its means that Slovak enterprises are more focused on conscientious behavior within the law, it's expected that they will rarely break the laws (that is more appropriative to performance of national economy). In table 4 we investigate the level of perception of business development by enterprises (table 4). 
Table 4 Results of survey of enterprises of Ukraine and Slovak of perception of business development

\begin{tabular}{|c|c|c|c|c|c|c|c|c|}
\hline & \multicolumn{2}{|c|}{ 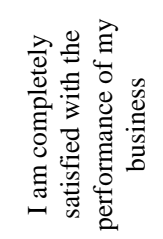 } & \multicolumn{2}{|c|}{ 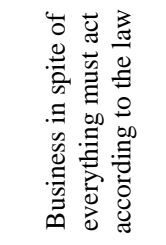 } & \multicolumn{2}{|c|}{ 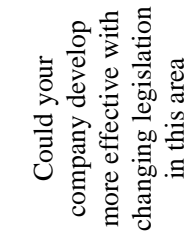 } & \multicolumn{2}{|c|}{ 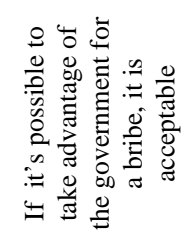 } \\
\hline & Ukr & Sk & Ukr & Sk & Ukr & Sk & Ukr & Sk \\
\hline Completely agree & 7,3 & 23,1 & 34,2 & 21,7 & 61 & 14,1 & 28,9 & 27,8 \\
\hline Rather agree & 21,9 & 23,1 & 19,5 & 8,2 & 19,6 & 14,1 & 15,8 & 19 \\
\hline 50 on 50 & 9,8 & 25,6 & 19,5 & 16,2 & 14,6 & 17,9 & 23,7 & 16,5 \\
\hline Rather disagree & 22 & 16,7 & 12,2 & 21,7 & 0 & 16,6 & 2,6 & 12,6 \\
\hline Do not Agree & 39,1 & 11,5 & 14,7 & 32,5 & 4,8 & 37,2 & 29 & 24,1 \\
\hline Correlation & \multicolumn{2}{|c|}{$-0,89$} & \multicolumn{2}{|c|}{$-0,16$} & \multicolumn{2}{|c|}{$-0,45$} & \multicolumn{2}{|l|}{0,84} \\
\hline
\end{tabular}

As we can see from this study, Slovak companies is more satisfied of performance of business (correlation is strongly negative -0,89). So Ukrainian enterprises are unsatisfied of business performance, which may assume, that Ukrainian enterprises is more paternalistic than Slovaks one. But at the same time Slovaks don't believe that business should act according to the law (in spite of its quality). So Slovak enterprises is more carry about quality of laws in this sphere, and can act opposite in case the law is ineffective. So statement than Ukrainian enterprises is more paternalistic confirms the fact that according to indicator «Could your company develop more effective with changing legislation in this area» Ukrainian enterprises is more agree with that than Slovak ones (correlation is negative -0,45). And last indicator of opportunistic behavior "If it's possible to take advantage of the government for a bribe, it is acceptable» Ukrainian enterprises is more agree with that, that means that enterprises is more subject to opportunistic behavior.

\section{Conclusions}

On base of this research following conclusions could be done:

1. National culture may affect the behavior of enterprises in different ways by affecting perception of external world.

2. So Slovak and Ukrainian enterprises doing business in different ways. Both side enterprises mostly disagree with existing rules of the game in sphere of entrepreneurship, but Slovak enterprises are more radical in these questions.

3. Because of cultural differences enterprises act in different ways in these countries. Slovak people are more proud of their country, so they may want to act to give some surplus to country's budget. This assumption is confirmed by perception by them of unscrupulous behavior - Slovak entrepreneurs less willing to break laws, they more negative in perception of acceptance of bribes, tax evasion, and shadow economy.

4. In doing business entrepreneurs from Slovak republic more often rely on their own efforts, do not look for support from government agencies, 
developing in the framework of the existing legislation in this area (though they consider it is ineffective).

\section{References}

Adler, NJ (1986), International Dimensions of Organizational Behavior. Boston: Kent Publishing.

Aidis, R. (2006), Entrepreneurship in a Changing Environment: Analyzing the impact of transition stages on SME development, available on http://www.ncsb2006.se/pdf/Do\%20environmental\%20influences.pdf

Akerlof, G. and R. Kranton (2000), "Economics and Identity," Quarterly Journal of Economics, August.

Bornhorst, Fabian, A. Ichino, Karl Schlag and Eyal Winter (2005), "Trust and Trustworthiness Among Europeans: South - North Comparison", European Institute Working paper.

Boyd, R. \& P.J. Richerson (1994), The Evolution of Norms: An Anthropological View, in: Journal of Institutional and Theoretical Economics, 150, 72-87.

Busenitz, L. W., \& Lau, C.-M. (1996), A cross-cultural cognitive model of new venture creation. Entrepreneurship: Theory \& Practice, 20(4), 25-39.

Dallago, B. (2000), The Organisational and Productive Impact of the Economic System. The Case of SMEs, in: Small Business Economics, 15, 303.319.

Davidsson, P. (1995), Culture, structure, and regional levels of entrepreneurship. Entrepreneurship and Regional Development, 7 (1), 41-62.

DiMaggio, PJ (1988), “Interest and Agency in Institutional Theory,” in Institutional Patterns and Organizations. Ed. L. G.Zucker. Cambridge, MA: Ballinger, 322.

Domjahn, T. (2011), PHD THESIS SUMMARY: Informal institutions and economic development, URL http://ejpe.org/pdf/5-2-ts-1.pdf

Fukuyama, F. (1995), Trust: The Social Virtues and the Creation of Prosperity, London: Hamish Hamilton, 457 p.

Geertz, C. (1957), Ritual and social change. American Anthropologist, 59, 32-54.

Giannetti, M., Simonov A. (2004), On the determinants of entrepreneurial activity: social norms, economic environment and individual characteristics. Swedish Economic Policy Review, 11, 269-313.

Glaeser, E., R. La Porta, and F. Lopez-de-Silanes and A. Schleifer (2004), "Do Institutions cause Growth", NBER Working Paper no. W10568.

Guiso, L., Sapienza, P. and Zingales, L. (2006), Does culture affect economic outcomes? Journal of Economic Perspectives, 20(2), 23-48.

Henrich, Joseph, Robert Boyd, Sam Bowles, Colin Camerer, Herbert Gintis, Richard McElreath and Ernst Fehr (2001), "In search of Homo economicus: Experiments in 15 Small-Scale Societies.” American Economic Review, 91(2), 73-79.

Hernan Roxas et al. (2008), “An Institutional View of Local Entrepreneurial Climate,” Asia-Pacific Social Science Review 7, no. 1

Hofstede, G. (1980), Cultural Consequences: International Differences in Work Related Values. Beverly Hills, CA: Sage.

Hofstede, G., Bond, MH (1988), The Confucius connection: from cultural roots to economic growth. Organizational Dynamics, 16, 5-21.

Hoskisson, RE, L. Eden, C.M. Lau \& M. Wright (2000), Strategy in Emerging Economies, in: Academy of Management Journal, 43 (3), 249-267. 
Hunt, S., \& Vitell, S. (1986), A general theory of marketing ethics. Journal of Macromarketing, 8, 5-16.

Inglehart, R. et al (2000), "World values surveys and European values surveys, 19811984, 1990-1993 and 1995-1997”, Ann Arbor-Michigan, Institute for Social Research, ICPSR version.

La Porta, RF, Lopez-De-Silanes, A. Schleifer and R. Vishny (1999), "The quality of Government”, The Journal of Law, Economics and Organization, 15, 222-79.

Libman, A. (2007), Institutional Competition in the Post-Soviet Space, available on http://mpra.ub.uni-muenchen.de/10936/

Licht, AN, Goldschmidt, C., Schwartz, SH (2005), Culture, law, and corporate governance. International Review of Law and Economics, 25, 229-255.

Martinelli, A. (2004), "The Social and Institutional Context of Entrepreneurship," in Crossroads of Entrepreneurship. Eds. G.Corbetta, M.Huse, and D.Ravasi. New York: Springer, 58-74.

McGrath, R., MacMillan, I. (1992), More like each other than anyone else? Acrosscultural study of entrepreneurial perceptions. Journal of BusinessVenturing, 7 (5), 419-429.

North, DC (1990), Institutions, Institutional Change and Economic Performance. Cambridge University Press, Cambridge, UK.

Parsons, T., \& Shils, E. (1990), Values and social systems. In: J. Alexander \& S. Seidman (Eds.), Culture and society, contemporary debates. Cambridge University Press: New York.

Paul, G. (2001), Hare Institutional Change and Economic Performance in the Transition Economies Vol. XLV, No. 10., 4-34.

Peng, M. \& Heath PS (1996), The Growth of the Firm in Planned Economies in Transition:Institutions, Organizations, and Strategic Choice, in: Academy of Management Review, 21 (2), 492-528.

Peng, M. (2000), Business Strategies in Transition Economies, Thousand Oaks, CA, London and New Delhi: Sage.

Puffer, M. (1993), A Riddle Wrapped in an Enigma: Demystifying Russian Managerial Motivation. European Management Journal, 11, 473-480.

Rabin, M. (1993), "Incorporating Fairness into Game Theory and Economics", American Economic Review, 83, 1281-1302.

Schwartz, S. (1994), Are there universal aspects in the structure and content of human values? Journal of Social Issues, 50, 19-45.

Tabellini, G. (2005), 'Culture and Institutions: Economic Development in the Regions of Europe', CESIFO Working Paper, No.1492.

Thomas, A. \& Mueller, S. (2000), A case for comparative entrepreneurship: assessing the relevance of culture. Journal of International Business Studies, 31(2), 287301.

Von Hirschhausen, C. (2000), Power Utility Re-Regulation in East European and CIS Transformation Countries (1990-1999): An Institutional Interpretation, available on http://www.hks.harvard.edu/hepg/Papers/discussion_paper_tu.pdf

Weggel, O. (1989), Die Asiaten, München: Deutscher Taschenbuchverlag.

Welter F. (2004) Culture versus branch? Looking at trust and entrepreneurial behavior from a cultural and sectoral perspective Trust and Entrepeneurship: A West-East Perspective, Publisher: Elgar, Editors: Hans-Hermann Höhmann, Friederike Welter.

Welter, F. (2002), Trust, Institutions and Entrepreneurial Behaviour. Bremen: Research Centre for East European Studies (FSOE). 
INFLUENCE OF NATIONAL CULTURE ON BEHAVIOR OF BUSINESS: COMPARATIVE STUDY OF SLOVAKIA AND UKRAINE

Welter, F., \& Smallbone, D. (2005), Entrepreneurship and enterprise strategies in transition economies: An institutional perspective. In F. Sjoholm, \& F. Tongzon (Eds.), Institutional change in Southeast Asia. London: Routledge Curzon.

Williamson, OE (1998), The institutions of governance. American Economic Review, $88,75-79$.

Williamson, OE (2000), The new institutional economics: taking stock, looking ahead, Journal of Economic Literature, 38, 595-613. 